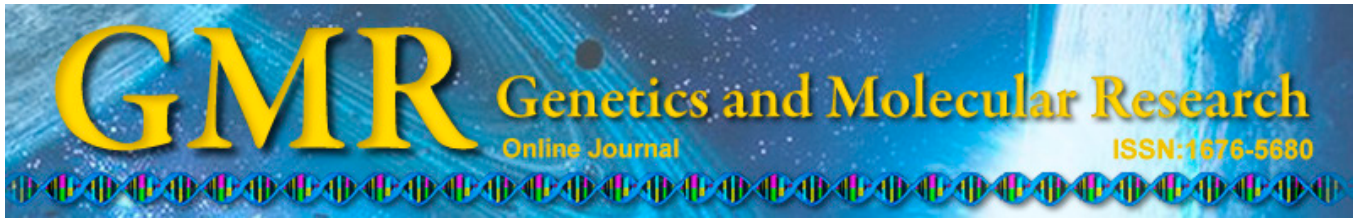

\title{
Registries of cases with neural tube defects in Denizli, Turkey, 2004-2010
}

\author{
A.G. Tomatir ${ }^{1}$, B. Kiray Vural' I. Acikbas $^{1}$ and B. Akdag ${ }^{3}$ \\ ${ }^{1}$ Department of Medical Biology, Faculty of Medicine, Pamukkale University, \\ Denizli, Turkey \\ ${ }^{2}$ Healthcare Services Vocational School, Denizli, Turkey \\ ${ }^{3}$ Department of Biostatistics, Faculty of Medicine, Pamukkale University, \\ Denizli, Turkey \\ Corresponding author: B. Kiray Vural \\ E-mail: bvural@pau.edu.tr
}

Genet. Mol. Res. 13 (4): 8537-8543 (2014)

Received January 16, 2014

Accepted March 25, 2014

Published October 20, 2014

DOI http://dx.doi.org/10.4238/2014.October.20.30

\begin{abstract}
Neural tube defects (NTD) are among the most common congenital abnormalities, with an incidence of 3 per 1000 live births in Turkey. In a study of major congenital abnormalities in the city of Denizli, Turkey, abnormalities of the central nervous system are particularly common (31.1\%). The objective of this study was to develop a registry of cases with NTDs in Denizli. Cases that had been diagnosed with NTD between January 2004 and September 2010 in State Hospitals of Central Denizli were retrospectively examined. The diagnoses were established based on the ICD-10 criteria. A total of 250 subjects with NTD were identified, including 123 (49.2\%) females and $127(50.8 \%)$ males with a mean age of $13.72 \pm 15.62$ years (age range 1-81 years). Interestingly, spina bifida constituted a significant percentage of the cases (149 cases; 59.6\%). In addition, $10(4.0 \%)$ cases had hydrocephalus plus spina bifida. The second most common diagnosis was microcephaly, which included 70 cases $(28.0 \%)$. Encephalocele was observed in only 2 cases $(0.8 \%)$. Development of NTD is influenced by nutrition, socioeconomic factors, and the use
\end{abstract}


of folic acid during the peri-conceptional period. Studies examining the effect of these factors on NTD in Turkey and a review of primary prevention measures are necessary.

Key words: Folic acid; Neural tube defect; Registry; Spina bifida; Turkey

\section{INTRODUCTION}

Neural tube defects (NTD) are among the most common congenital abnormalities and are a major cause of infantile and childhood deaths (Tolmie, 1996; Cengiz et al., 2004; Medveczky and Puho, 2004). The most common forms of NTD include anencephaly and spina bifida. Anencephaly is a congenital defect resulting from impaired closure of the top of the neural tube; these infants die shortly after birth (Tinkle and Sterling, 1997; Reeder et al., 1997).

Loss of the Sox2 gene was the most frequently observed genetic abnormality in subjects with NTDs (16\%). Although Nanog3 upregulation is observed in $48 \%$, Oct 4 and Sox 2 in $40 \%$ of the patients, the differences were not significant, only null mutation was significantly correlated with NTD (Saxena et al., 2013). The most common maternal risk factors associated with NTDs in infants include folic acid deficiency, overweight, diabetes, drugs, consanguinity, and single-nucleotide polymorphisms (Kondo et al., 2009; Herrmann and Obeid, 2011; Carter et al., 2011). The prevalence of NTDs at birth varies significantly by national geographical strata, ethnicity, and racial groups. Worldwide, 250,000 NTDs are diagnosed annually during pregnancy (Wald et al., 2001). The frequency of NTD has been reported to be $0.1 \%$ in Europe and $0.2 \%$ in the USA (American Academy of Pediatrics, 1993; Friel et al., 1995). The incidence of spina bifida and anencephaly in 10,000 live births is 0.9 in Canada, 7.7 in the United Arab Emirates, 0.7 in France, and 11.7 in South America (Tolmie, 1996). This rate is 1 in 100 in some parts of China and 1 or less in 5000 births in Scandinavian countries (Botto and Yang, 2000).

NTDs are among the most severe congenital abnormalities in Turkey; epidemiological findings indicate that prevalence rates vary with regional and demographic features. However, this information is currently not available in the Turkish medical registry system (Tunçbilek, 2004); according to data obtained from various cities of Turkey (Akar et al., 1989; Mocan et al., 1992; Posaci et al., 1992; Güvenc et al., 1993; Himmetoğlu et al., 1996; Tunçbilek et al., 1999), the prevalence of NTD ranges from 3-5.8 per 1000 births (Tunçbilek, 2004). Rates as high as 8.9 in Izmir and 20.0 per 1000 births in Mustafa Kemal Pasa of Bursa have been recorded following the Chernobyl disaster (Hoffmann, 2001). A university clinical study demonstrated that the frequency of NTD is highest in Northern and Eastern Anatolia, with an incidence of 4.32 and 4.54 per 1000 live births, and is lowest in Western Anatolia, with an incidence of 2.17 per 1000 live births. This rate was 9.1 per 1000 live births in uneducated mothers who were evaluated based on maternal education level (Tunçbilek, 2004). A study by Bati et al. (2007) revealed that the incidence of NTD was 1.5 in 1000 births in all hospitals in Izmir. In Afyonkarahisar, the incidence of NTD was found to be 3.58 in 1000 live births (Onrat et al., 2009). Abnormalities of the central nervous system rank highest among studies investigating the registries of major congenital abnormalities in Denizli (31.1\%) (Tomatir et al., 2009). The objective of this study was to identify NTD cases in registries of Denizli, highlight the disease incidence, and suggest appropriate measure that may be taken in Turkey. 


\section{MATERIAL AND METHODS}

This descriptive and retrospective study on NTD survival was performed in two hospitals (Servergazi and Denizli State Hospitals) in Denizli, Turkey between January 2004 and September 2010. NTDs were defined according to the ICD-10 criteria. Data were analyzed using the Statistical Package for the Social Sciences, v. 10 (SPSS Inc., Chicago, IL, USA). Descriptive statistics are presented as frequencies and percentages.

\section{RESULTS}

Totally 250 NTD cases were identified in the registries of Denizli State Hospital in $52.3 \%$ and Servergazi State Hospital in 47.7\% from September 1-30, 2010. There were $123 \mathrm{fe}$ males (49.2\%) and 127 males (50.8\%), with a mean age of $13.72 \pm 15.62$ years (range, 1-81). A total of 149 spina bifida cases $(59.6 \%)$, and 10 cases with spina bifida plus hydrocephalus $(4.0 \%)$ were identified. Seventy cases had been diagnosed with microcephaly $(28.0 \%)$ and 2 with encephalocele $(0.8 \%)$. Other less frequent findings are presented in Table 1. Approximately half of the NTDs (44.8\%) were under the age of 5 years (Table 2).

\begin{tabular}{|c|c|c|c|c|c|c|c|}
\hline \multirow[t]{3}{*}{ NTDs } & \multirow[t]{3}{*}{ ICD-10 code } & \multirow[t]{3}{*}{$\mathrm{N}$} & \multirow[t]{3}{*}{$(\%)$} & \multicolumn{4}{|c|}{ Gender } \\
\hline & & & & \multicolumn{2}{|c|}{ Female } & \multicolumn{2}{|c|}{ Male } \\
\hline & & & & $\mathrm{N}$ & $(\%)$ & $\mathrm{N}$ & $(\%)$ \\
\hline Spina bifida & Q05 & 149 & $(59.6)$ & 67 & $(54.5)$ & 82 & $(64.6)$ \\
\hline Microcephaly & Q02 & 70 & $(28.0)$ & 37 & $(30.1)$ & 33 & $(26.0)$ \\
\hline Spina bifida and hydrocephaly & Q05.2 & 10 & $(4.0)$ & 8 & $(3.5)$ & 2 & $(1.6)$ \\
\hline NTD and other anomalies & Q06 & 11 & $(4.4)$ & 7 & $(2.7)$ & 4 & $(3.1)$ \\
\hline Other cerebral anomalies & Q04 & 7 & $(2.8)$ & 4 & (1.6) & 3 & $(2.4)$ \\
\hline Encephalocele & Q01 & 2 & $(0.8)$ & - & $(0.0)$ & 2 & (1.6) \\
\hline Malformation of aquaductus silvii & Q03.0 & 1 & $(0.4)$ & - & $(0.0)$ & 1 & $(0.8)$ \\
\hline Total & & 250 & $(100.0)$ & 123 & $(49.2)$ & 127 & $(50.8)$ \\
\hline
\end{tabular}

NTDs $=$ neural tube defects; $\mathrm{N}=$ number of cases.

\begin{tabular}{lrr} 
Table 2. Distribution of neural tube defects (NTDs) by age. & $\%$ \\
\hline Age (years) & N & 44.8 \\
\hline $0-5$ & 112 & 9.2 \\
$6-10$ & 23 & 10.8 \\
$11-15$ & 27 & 9.6 \\
$16-20$ & 24 & 6.8 \\
$21-25$ & 17 & 4.0 \\
$26-30$ & 10 & 4.4 \\
$31-35$ & 11 & 3.2 \\
$36-40$ & 8 & 2.0 \\
$41-45$ & 5 & 2.4 \\
$46-50$ & 6 & 0.4 \\
$51-55$ & 1 & 0.0 \\
$56-60$ & 0 & 0.8 \\
$61-65$ & 2 & 1.2 \\
$66-70$ & 3 & 0.4 \\
$>71$ & 1 & 100 \\
\hline Total & 250 & \\
\hline
\end{tabular}




\section{DISCUSSION}

The European Registration of Congenital Abnormalities and Twins (EUROCAT) reported a significantly higher prevalence of NTDs in most European countries compared to countries with micronutrient fortification programs (www.eurocat-network.eu). The mean rate of NTD in the EUROCAT was 7.88 per 10,000 births from 2004-2008 (Herrmann and Obeid, 2011; Khoshnood et al., 2011). The incidence of NTD in Turkey is even greater than that in Europe and the USA. Also Tunçbilek et al. (1999) reported that the rate of NTD is 1.20 in Turkey. In another study in Turkey, 100 (1.2\%) of 8408 infants admitted to the neonatal intensive care unit were diagnosed with NTD during the study period. Prenatal diagnosis was made in $72 \%$ of cases, but the parents chose to continue the pregnancy. The most frequent type and site of NTD was meningomyelocele (82\%) of the lumbosacral region (36\%) (Aygün et al., 2013).

In this study, spina bifida was the most frequently observed condition (149 cases; $59.6 \%$ ), followed by microcephaly (70 cases; $2.0 \%$ ). In addition, 10 cases $(4.0 \%)$ were determined to have hydrocephaly plus spina bifida. Encephalocele was found in only 2 cases $(0.8 \%)$. In a similar study, Rankin et al. (2000) reported a total of 984 NTD cases, including 403 (43.1\%) cases of anencephaly, $472(50.5 \%)$ spina bifida, and $59(6.3 \%)$ encephalocele. Zlotogora et al. (2002) reported 401 NTD cases (167 cases of anencephaly, 167 cases of spina bifida, 48 cases of encephalocele, and 19 cases with other malformations) between the years 1999-2000. Twentythree pregnancies were affected by anencephaly, 3 with spina bifida, and 1 with encephalocele. The anencephaly rate was 8.4 per 10,000 live births [ $95 \%$ confidence interval $(\mathrm{CI})=4.5-12.0$ ], compared with a national estimate of 2.1 per 10,000 live births $(\mathrm{CI}=1.9-2.2)$. In contrast, the rate of spina bifida was 1.3 per 10,000 live births $(\mathrm{CI}=0.3-3.8)$, compared with 3.5 per 10,000 live births nationally ( $\mathrm{CI}=3.3-3.7)$ (Centers for Disease Control and Prevention, 2013).

Environmental factors are well known to affect the etiology of neural tube defects (Rankin et al., 2000). Women who smoked during pregnancy showed a mildly elevated risk [odds ratio $(\mathrm{OR})=1.03,95 \% \mathrm{CI}=0.80-1.33$ ] of having infants with NTDs (Wang et al., 2014). The geographical distribution of NTDs in Turkey indicates a relationship between the development of NTDs and socioeconomic and environmental factors. Although some polymorphisms leading to genetic effects have been demonstrated in studies worldwide (Botto and Yang, 2000; Pangilinan et al., 2010; Carter et al., 2011), the specific genes and genetic factors involved have yet to be determined. A $677 \mathrm{C} \rightarrow \mathrm{T}$ mutation in the methylenetetrahydrofolate reductase gene, which is thought to cause NTDs, is not a risk factor in the Turkish population (Boduroğlu et al., 1999). The large differences observed in the incidence of NTD according to maternal education, age, and socio-economic factors have suggested that in addition to potential genetic factors, various environmental factors, such as nutrition, play major roles in disease incidence. Studies examining the causative role of folic acid deficiency in NTD in different countries have demonstrated that improvement in maternal folic acid levels prevented NTD recurrence and decreased NTD incidence (Tunçbilek, 2004).

Folates and vitamin B12 play fundamental roles in central nervous system function at all ages, particularly in purine, thymidine, nucleotide, and DNA synthesis, as well as genomic and nongenomic methylation, and therefore in tissue growth, differentiation, and repair (Reynolds, 2014). The mandatory fortification of staple foods rich in folic acid to prevent NTDs began in the USA in 1998. Since then, more than 50 countries worldwide have implemented similar programs (Herrmann and Obeid, 2011). Peri-conceptional use of folic acid in women of child-bearing potential has significantly decreased the incidence of NTD in England and 
Ireland (Rankin et al., 2000). A study performed in Ontario, Canada found that the prevalence of NTDs decreased from 1.13 to 0.58 per 1000 births in women following fortification with food with an additional $0.2 \mathrm{mg}$ folic acid content (Ray et al., 2002). A rate of 54\% was reported in another study performed in a different region of Canada (Nova Scotia) (Persad et al., 2002). Another study performed in Canada found that fortification of foods led to a $100-\mu \mathrm{g}$ increase in daily folic acid intake in adults. However, the $400 \mu \mathrm{g}$ daily folic acid requirement is not being met (French et al., 2003). Replacement with folic acid tablets in addition to fortification of foods appears to be the most effective method for meeting this need. Various studies performed in these countries demonstrated that the rate of use of folic acid tablets remains at $30 \%$ because of factors such as lack of information, cost, and dislike of the tablet (Tunçbilek, 2004).

Most infants with NTDs die in the first year after birth. In this study, approximately half of the NTDs were less than 5 years old. Aygün et al. (2013) reported that in $80 \%$ of the babies, the NTD sac was closed within the first $72 \mathrm{~h}$ of life. The most frequently observed postoperative complications included wound infection and septicemia. The mortality rate of infants with NTD during the follow-up period was 7\%, and all deaths occurred in the first year of life. Sixty-two percent of the patients were found to have neurological deficits upon followup. Patients were re-hospitalized during the follow-up period an average of 2.9 times.

These results indicate the important role of health care providers in informing the public and patients. In addition, the role of mass media should not be disregarded and should be used effectively.

\section{Strengths and limitations}

Data were obtained from 3 different registry systems. The data was entered into the system by specialist physicians. Only NTD cases that had survived after birth could be reached for participation in this survey. No information regarding concomitant syndromes was provided. Information regarding the mother or family could not be obtained. Thus, these data do not include infants that have not yet been born or terminated pregnancies. Therefore, prevalence has not been provided in this study since it does not conform to other national data. Better registry systems for compiling national data should be developed. Information regarding prenatal screening, prenatal diagnosis, results of pregnancy screening, and family considerations should be included in the registry forms.

\section{CONCLUSIONS}

New education methods should be developed in addition to fortification of food rich in folic acid and supplementation with folic acid tablets to decrease the high incidence of NTDs. New strategies should be determined by the Ministry of Health as well as by universities, nongovernmental organizations, and related institutions. Further studies should be performed to determine the differences in the incidence and distribution of NTD as well as etiological and genetic factors in Turkey. In addition, a better national registry system should be developed.

\section{ACKNOWLEDGMENTS}

The authors would like to thank Denizli State Hospitals for allowing us analyze the NTD data for this study. 


\section{REFERENCES}

Akar N, Ata Y and Aytekin AF (1989). Neural tube defects and Chernobyl? Paediatr. Perinat. Epidemiol. 3: 102-103. American Academy of Pediatrics (1993). Folic acid for the prevention of neural tube defects. Pediatrics 92: 493-494.

Aygün C, Kurucu S, Cakmak-Çelik F, Dağçınar A, et al. (2013). Experience of a tertiary care center on 100 newborns with neural tube defects. Turk. J. Pediatr. 55: 359-364.

Bati H, Mandıracıoğlu A, Turgul Ö, Akkol S, et al (2007). Key Roles in Preventing Neural Tube Defects: Counselling by Health Staff (Nöral Tüp Defektlerinden Korunmada Anahtar Rol: Saglik Personelinin Danismanligi). STED 16: 110118. Available at [http://www.ttb.org.tr/STED/images//files/dergi/2007/kasim/index.pdf]. Accessed June 26, 2013.

Boduroğlu K, Alikaşifoğlu M, Anar B and Tunçbilek E (1999). Association of the 677 C-T mutation on the methylenetetrahydrofolate reductase gene in Turkish patients with neural tube defects. J. Child Neurol. 14: 159-161.

Botto LD and Yang Q (2000). 5,10-Methylenetetrahydrofolate reductase gene variants and congenital anomalies: a HuGE review. Am. J. Epidemiol. 151: 862-877.

Carter TC, Pangilinan F, Troendle JF, Molloy AM, et al. (2011). Evaluation of 64 candidate single nucleotide polymorphisms as risk factors for neural tube defects in a large Irish study population. Am. J. Med. Genet. A 155A: 14-21.

Cengiz B, Söylemez F, Öztürk E and Çavdar AO (2004). Serum zinc, selenium, copper, and lead levels in women with second-trimester induced abortion resulting from neural tube defects: a preliminary study. Biol. Trace Elem. Res. 97: 225-235.

Centers for Disease Control and Prevention (CDC) (2013). Notes from the field: investigation of a cluster of neural tube defects - central Washington, 2010-2013. MMWR Morb. Mortal. Wkly. Rep. 62: 728.

French MR, Barr SI and Levy-Milne R (2003). Folate intakes and awareness of folate to prevent neural tube defects: a survey of women living in Vancouver, Canada. J. Am. Diet. Assoc. 103: 181-185.

Friel JK, Frecker M and Fraser FC (1995). Nutritional patterns of mothers of children with neural tube defects in Newfoundland. Am. J. Med. Genet. 55: 195-199.

Güvenc H, Uslu MA, Güvenc M, Özekici U, et al. (1993). Changing trend of neural tube defects in eastern Turkey. $J$. Epidemiol. Community Health 47: 40-41.

Herrmann W and Obeid R (2011). The mandatory fortification of staple foods with folic acid: a current controversy in Germany. Dtsch. Arztebl. Int. 108: 249-254.

Himmetoğlu O, Tiraş MB, Gürsoy R, Karabacak O, et al. (1996). The incidence of congenital malformations in a Turkish population. Int. J. Gynaecol. Obstet. 55: 117-121.

Hoffmann W (2001). Fallout from the Chernobyl nuclear disaster and congenital malformations in Europe. Arch. Environ. Health 56: 478-484.

Khoshnood B, Greenlees R, Loane M and Dolk H (2011). Paper 2: EUROCAT public health indicators for congenital anomalies in Europe. Birth Defects Res. A Clin. Mol. Teratol. 91 (Suppl 1): S16-S22.

Kondo A, Kamihira O and Ozawa H (2009). Neural tube defects: prevalence, etiology and prevention. Int. J. Urol. 16: 49-57.

Medveczky E and Puho E (2004). Parental employment status and neural-tube defects and folic acid/multivitamin supplementation in Hungary. Eur. J. Obstet. Gynecol. Reprod. Biol. 115: 178-184.

Mocan H, Aydemir V, Bozkaya H, Mocan MZ, et al. (1992). Incidence of neural tube defects (NTD) in Ankara, Turkey, prior to and after the Chernobyl disaster. Paediatr. Perinat. Epidemiol. 6: 111-114.

Onrat ST, Seyman H and Konuk M (2009). Incidence of neural tube defects in Afyonkarahisar, Western Turkey. Genet. Mol. Res. 8: 154-161.

Pangilinan F, Mitchell A, VanderMeer J, Molloy AM, et al. (2010). Transcobalamin II receptor polymorphisms are associated with increased risk for neural tube defects. J. Med. Genet. 47: 677-685.

Persad VL, Van den Hof MC, Dube JM and Zimmer P (2002). Incidence of open neural tube defects in Nova Scotia after folic acid fortification. CMAJ 167: 241-245.

Posaci C, Celiloğlu M and Karabacak O (1992). The epidemiology of neural tube defects in Izmir, Turkey. Int. J. Gynaecol. Obstet. 39: 135-136.

Rankin J, Glinianaia S, Brown R and Renwick M (2000). The changing prevalence of neural tube defects: a populationbased study in the north of England, 1984-96. Northern Congenital Abnormality Survey Steering Group. Paediatr. Perinat. Epidemiol. 14: 104-110.

Ray JG, Meier C, Vermeulen MJ, Boss S, et al. (2002). Association of neural tube defects and folic acid food fortification in Canada. Lancet 360: 2047-2048.

Reeder SJ, Martin LL and Koniak-Grifin D (1997). Maternity Nursing: Family, Newborn and Women's Health Care. 18th edn. Lippincott Williams and Wilkins, Philadelphia, 450-454. 
Reynolds EH (2014). The neurology of folic acid deficiency. Handb. Clin. Neurol. 120: 927-943.

Saxena AK, Pandey S and Pandey LK (2013). Genetic diversity of stem cells and their functional impact on the development of neural tube defects in Eastern population of India. Genet. Mol. Res. 12: 2380-2390.

Tinkle MB and Sterling BS (1997). Neural tube defects: a primary prevention role for nurses. J. Obstet. Gynecol. Neonatal Nurs. 26: 503-512.

Tolmie JL (1996). Neural Tube Defects and Other Congenital Malformations of the Central Nervous System. In: Emery and Rimoin's Principles and Practice of Medical Genetics. 3rd edn. (Rimoin DL, Connor JM and Pyeritz RE, eds.). Churchill Livingstone, London, 2152.

Tomatir AG, Demirhan H, Sorkun HÇ, Köksal A, et al. (2009). Major congenital anomalies: a five-year retrospective regional study in Turkey. Genet. Mol. Res. 8: 19-27.

Tunçbilek E (2004). The high incidence of neural tube defects in Turkey what should be done for prevention? Turkish Pediatr. J. 47: 79-84. Available at [http://www.cshd.org.tr/csh/pdf/pdf_CSH_75.pdf]. Accessed September 15, 2013.

Tunçbilek E, Boduroglu K and Alikasifoglu M (1999). Neural tube defects in Turkey: prevalence, distribution and risk factors. Turk. J. Pediatr. 41: 299-305.

Wald NJ, Law MR, Morris JK and Wald DS (2001). Quantifying the effect of folic acid. Lancet 358: 2069-2073.

Wang M, Wang ZP, Gong R and Zhao ZT (2014). Maternal smoking during pregnancy and neural tube defects in offspring: a meta-analysis. Childs Nerv. Syst. 30: 83-89.

Zlotogora J, Amitai Y, Kaluski DN and Leventhal A (2002). Surveillance of neural tube defects in Israel. Isr. Med. Assoc. J. 4: 1111-1114. 